\title{
Globális és hazai éghajlati trendek, szélsőségek változása: 2020-as helyzetkép
}

\author{
Lakatos Mónika*, Bihari Zita, Izsák Beatrix, Szentes Olivér \\ Országos Meteorológiai Szolgálat, Budapest, Magyarország \\ Beérkezett: 2021. május 7.; Elfogadva: 2021. június 2.
}

\begin{abstract}
Összefoglalás
A WMO 2021 elején kiadott állapotértékelóje szerint a COVID-19 miatti korlátozások ellenére az üvegházhatású gázok légköri koncentrációja tovább emelkedett. A tengerszint emelkedés a közelmúltban gyorsult, rekordmagas volt a jégvesztés Grönlandon, az Antarktisz olvadása is gyorsulni látszik. Szélsőséges időjárás pusztított, élelmiszer-ellátási gondok léptek fel, és 2020-ban a COVID-19 hatásával együtt nőtt a biztonsági kockázat több régióban is. Az éghajlatváltozás felerősíti a meglévő kockázatokat, és újabb kockázatok is fellépnek majd a természeti és az ember által alkotott rendszerekben.

Az éghajlatváltozás hatása a hazai mérési sorokban is megjelenik. Az Országos Meteorológiai Szolgálat (OMSZ) homogenizált, ellenőrzött mérései szerint 1901 óta $1,2{ }^{\circ} \mathrm{C}$-ot nőtt az évi középhőmérséklet. Két normál időszakot vizsgálva egyértelmú a magasabb hômérsékletek felé tolódás, a csapadék éven belüli eloszlása megváltozott, az ôszi másodmaximum eltúnőben van. Nôtt az aszályhajlam, gyakoribbá váltak a hőhullámok, intenzívebb a csapadékhullás, emiatt az éghajlatvédelemi intézkedések mellett a jól megalapozott alkalmazkodás is indokolt. A biztonsági kockázatok csökkenthetők az OMSZ és Országos Katasztrófavédelmi Főigazgatóság közötti együttmúködés által.
\end{abstract}

Kulcsszavak: globális éghajlatváltozás, magyarországi éghajlati tendenciák, éghajlati normálok, éghajlati szélsőségek változása, éghajlatváltozás okozta biztonsági kockázatok

\author{
Global trends and climate change in Hungary in 2020 \\ Monika Lakatos, Zita Bihari, Beatrix Izsák, Olivér Szentes \\ Hungarian Meteorological Service (OMSZ), Budapest, Hungary
}

\begin{abstract}
Summary
The first part of the article gives an overview of the state of the global climate in 2020 based on the report compiled by the World Meteorological Organization (WMO, 2021) and network of partners from UN. According to this report, the 2020 was one of the three warmest years on record, despite a cooling La Niña event. The global mean temperature for 2020 (January to October) was $1.2 \pm 0.1^{\circ} \mathrm{C}$ above the $1850-1900$ baseline, used as an approximation of pre-industrial levels. The latest six years have been the warmest on record. 2011-2020 was the warmest decade on record. The report on the "State of the Global Climate 2020" illustrates the state of the key indicators of the climate system, including greenhouse gas concentrations, increasing land and ocean temperatures, sea level rise, melting ice and glacier and extreme weather. It also highlights impacts on socio-economic development, migration and displacement and food security. All key climate indicators and associated impact information published in this report highlight continuing climate change, an increasing occurrence and intensification of extreme events, and severe losses and damage, affecting people, societies and economies. Extreme weather events triggered an estimated 10000 000 displacements in 2020. Because of COVID-19 lockdowns, response and recovery operations were leading to delays in providing assistance. After decades of decline, the increase in food insecurity since 2014 is being driven by conflict and economic slowdown as well as climate variability and extreme weather events. Climate change will amplify existing risks and create new risks for natural and human systems. Risks are unevenly distributed and are generally greater for disadvantaged people and communities in countries at all levels of development.

The global changes have local effects in Hungary as it is shown in the second part of the article. The climate monitoring at the Hungarian Meteorological Service is based on measurements stored in the Climate data archive.
\end{abstract}


We apply data management tools to produce high quality and representative datasets to prepare climate studies. The data homogenization makes possible to eliminate inhomogeneities due to change in the measuring practice and station movements. Applying spatial interpolation procedure for meteorological data provide the spatial representativeness of the climate data used for monitoring. The surface temperature increase is slightly higher in Hungary than the global change from 1901. The annual precipitation decreased by $3 \%$ from 1901, although this change is not significant statistically. The monthly temperatures shifted to warmer monthly averages in the most recent normal period between 1991 and 2020 comparing to the 1961-1990 in each months. The annual course of the monthly precipitations changed, especially autumn. The monthly sum in September and in October increased substantially. The frequency of heatwave days increased by more than two weeks in the Little Plain and in the southern part of the Great Hungarian Plain from 1981, which is the most intense warming period globally. The intensification of the precipitation in the recent years is obvious in our region. The cooperation of the Disaster Risk Management and the Hungarian Meteorological Service could expand the adaptive capacity of the society to climate change.

Keywords: global climate change, climate trends in Hungary, climate normal, change of climate extremes in Hungary

\section{Bevezetés}

2020 decemberében volt az éghajlatváltozásról szóló párizsi megállapodás létrejöttének ötödik évfordulója. Minden jel arra mutat, hogy az eddigi kötelezettségvállalások az üvegházhatású gázok kibocsátásának csökkentése érdekében nem elegendőek ahhoz, hogy meg lehessen állítani a melegedést $1,5^{\circ} \mathrm{C}$-nál, de legfeljebb $2{ }^{\circ} \mathrm{C}$-on az iparosodás előtti átlaghoz képest, ahogy az a párizsi klímacélok között szerepel. Ennek a célnak, de különösen a melegedés másfél fokon tartásának az eléréséhez további erőfeszítésekre, vállalásokra van szükség a döntéshozók részéről. A 2020 novemberére, Glasgow-ba tervezett COP26 (Conference of the Parties) ülést, ahol már konkrétumokkal kellett volna elöállni az országoknak az ígéretek mellett, 2021-re kellett halasztani a COVID-helyzet miatt. Mindeközben sorra jelennek meg olyan értékelések a bolygó éghajlati állapotáról, amelyek sürgetőnek látják a cselekvést. A felelős klímapolitikai döntések meghozatalát, illetve az alkalmazkodási folyamatot segíti a Meteorológiai Világszervezet (WMO) több ENSZ szervezettel együtt kidolgozott éghajlati állapotot értékelő jelentése, amit 1993 óta évente nyilvánosságra hoz. A 2020 évi értékelő (WMO 2021) fóbb megállapításairól számolunk be ebben a cikkben, rámutatva az éghajlatváltozás okozta biztonsági kockázatokra. Ezenkívül bemutatjuk a naprakész hosszú távú hazai hőmérséklet és csapadék trendeket, az átlagok eltolódását és néhány éghajlati szélsőség időbeli alakulását. Az Országos Meteorológiai Szolgálat és az Országos Katasztrófavédelmi Főigazgatóság (OKF) között szoros az együttmúködés a szélsőséges időjárási események nyomon követésében, a hatások lehetséges megelőzésében és mérséklésében, nemcsak az OMSZ veszélyjelző rendszerét tekintve, hanem az éghajlatváltozás biztonsági kockázatát csökkentő folyamatok tervezésében. Ezekre az aspektusokra is utalunk a cikkben.

\section{Hol tart a melegedés globálisan?}

A számos nemzetközi szervezet és szakértő közremúködésével készült WMO-jelentés rámutat arra, hogy a nagy hatású események, köztük a hőhullámok, erdőtüzek és áradások, valamint a rekorderôs atlanti hurrikánszezon komoly hatással voltak emberek millióira 2020-ban. Ezek az események fokozták a COVID-19 járvány miatti fenyegetettséget, ami az egészségre, biztonságra és a gazdasági stabilitásra is hatott. A COVID-19 miatti korlátozások ellenére az üvegházhatású gázok légköri koncentrációja tovább emelkedett. A jelentés arra is felhívja a figyelmet, hogy a melegedés hatását generációk sora fogja még érzékelni a jövőben a szén-dioxid hosszú légköri tartózkodási ideje miatt. Tény, hogy a fö üvegházhatású gázok, a szén-dioxid, a metán és a nitrogén-dioxid koncentrációja 2019-ben és 2020-ban is tovább nőtt.

A 2020. évi globális középhőmérséklet a három legmagasabb egyike a La Niña viszonyok ellenére (a La Niña állapot lényege, hogy szokásosnál hidegebb a tengervíz a Csendes-óceán kelleti medencéjének trópusi területein, ez az El Niño esemény ellentétes párja). Az elmúlt hat év az eddigi legmelegebb hat év a szisztematikus mérések kezdete óta, a 2011-2020 dekád pedig a legmelegebb tíz év. A globális átlaghőmérséklet 2020-ban $1,2{ }^{\circ} \mathrm{C}$-kal volt magasabb, mint az iparosodás előtti, 1850-1900 közötti időszak átlaga. Elérte a hőmérséklet a $38,0^{\circ} \mathrm{C}$-ot Verhojanszkban június 20 -án, ez volt a legmagasabb érték, amit a sarkkörtól északra valaha mértek. Ezek mind aggasztó tények és jelek, úgy tünik, hogy gyorsul a melegedés folyamata, ami számos változást eredményez az éghajlati rendszerben.

A tengerszint-emelkedés nem döntött rekordot, de a közelmúltban gyorsult, részben a grönlandi és az antarktiszi jégtakaró olvadásának köszönhetően. A globális átlagos tengerszint 2020-ban hasonló volt a 2019-eséhez, mindkettő összhangban van a hosszú távú trenddel. 2020 második felében a globális tengerszint csekély 
csökkenése valószínúleg a La Niña esemény kialakulásához köthető, hasonlóan a korábbi La Niña állapotok miatti átmeneti csökkenésekhez.

Az Északi-sarkvidéken az éves minimális tengerijég-kiterjedés a második legalacsonyabb volt 2020-ban, és rekord alacsony kiterjedést figyeltek meg júliusban és októberben is. A Laptev-tengeren a legkorábbi jégolvadás volt megfigyelhető a müholdas mérések kezdete óta. A grönlandi jégvesztés folytatódott, noha a felszíni jégtömeg-mérleg átlag körüli volt, a jégborjadzás (tengerbe nyúló gleccserek végeinek leszakadása) miatti jégveszteség 40 év múholdas mérései szerint a legnagyobb volt. 2020-ban az Antarktiszon az 1981-2010-es átlag közelében alakult a jégkiterjedés. Az antarktiszi tengeri jég állapota 2005-ig viszonylag stabil volt, de azóta gyorsuló olvadás figyelhető meg. Az antarktiszi jégvesztés felgyorsult 2005-től. Jelenleg körülbelül 175-225 Gt tömegú jég olvad el évente a Déli-sarkvidéken.

Az óceánoknak kitüntetett szerepük van az éghajlatváltozás folyamatában. Az emberi tevékenységből eredő szén-dioxid éves kibocsátásának mintegy 23\%-át elnyelik, és pufferként múködnek, ez azonban az óceánok savasodásához vezet, ami viszont csökkenti a víz szén-dioxid-elnyelő képességet. Ezenkívül az emberi tevékenység okozta hőtöbblet több mint 90\%-át elnyelik, ez abban is megnyilvánult, hogy 2019-ben az óceáni hőtartalom a legmagasabb volt az eddig mértek alapján. Az elmúlt évtizedben ez a folyamat gyorsult, ami azt jelzi, hogy az üvegházhatású gázok okozta hőtöbblet melegíti az óceánokat is.

\section{Az éghajlatváltozás okozta globális biztonsági kockázatok 2020-ban}

A WMO koordinációjában készült jelentés kitér arra is, hogy körülbelül 10 millióan kényszerültek elhagyni lakhelyüket elsősorban áradások, földcsuszamlások és aszályok miatt 2020 első felében a Földön, fóként Délés Délkelet-Ázsiában és Afrika szarván. 2020-ban a COVID-19 járvány újabb dimenzióval bővítette a népességmozgással kapcsolatos aggályokat. A COVID-19 járvány plusz kockázatot, illetve nehézséget jelentett az időjárási katasztrófák miatti evakuálási, helyreállítási és segélyezési múveletek során. Például a Fülöp-szigeteken, május közepén előzetesen több mint 180000 embert evakuáltak a Vongfong (Ambo) trópusi ciklon előtt, a vírushelyzet miatti távolságtartási intézkedések betartása miatt azonban a lakosokat nem lehetett nagy számban szállítani, és a kitelepítési központok is csak fél kapacitással múködtek.

Tízévnyi csökkenés után az élelmezés bizonytalansága újra növekszik 2014 óta a társadalmi konfliktusok, a gazdasági hanyatlás, valamint az éghajlat változékonysága és az extrém időjárási események miatt. A FAO (ENSZ Élelmezésügyi és Mezőgazdasági Szervezete) legfrissebb adatai szerint közel 690 millió ember, vagyis a világ népességének 9\%-a volt alultáplált, és körülbelül 750 mil- lióan éltek át súlyos élelmiszerválságot 2019-ben. A gazdasági és társadalmi krízis és egyéb veszélyek miatt éhínségben szenvedő emberek száma 55 országban csaknem 135 millióra nőtt (FAO 2020).

A FAO és a WFP (World Food Programme) adatai szerint több mint 50 millió embert sújtott dupla teher: az éghajlattal kapcsolatos katasztrófák (áradások, aszályok és viharok) és a COVID-19 járvány. Közép-Amerika országai hármas hatástól szenvednek: az Eta és Iota hurrikánok pusztításától, a COVID-19 járványtól és az egyébként is meglévő humanitárius válságoktól. A hondurasi kormány becslése szerint 53000 hektár termőterületen oda lett a termés, fóleg rizst, babot és cukornádat mostak el az áradások (FAO 2020).

\section{Növekvő biztonsági kockázatok globálisan}

Az IPCC 5. értékelőjének „Szintézis riportja” (IPCC, 2014a) megállapítja, hogy az éghajlatváltozás felerősíti a meglévő kockázatokat, és újabb kockázatok is megjelennek majd várhatóan a természeti és az ember által alkotott rendszerekben. Arra is rámutat, hogy nagyobb mértékben érintik ezek a kockázatok a hátrányos helyzetü embereket és közösségeket, bármilyen fejlettségi szintű is egy adott ország. A melegedés növekvő üteme és nagyságrendje, az éghajlati rendszerben tapasztalt egyéb változások, mint például az óceánok savasodása növelik a súlyos, átfogó és esetenként visszafordíthatatlan káros hatások kockázatát. Vannak olyan veszélyek, amelyek csak egyes régiókat érintenek, míg másokkal mindenhol számolni kell. A jövőbeli éghajlatváltozás okozta kockázatok azonban csökkenthetők, ha az éghajlatváltozás ütemét és nagyságrendjét sikerül korlátok közé szorítani. (IPCC 2014b).

A Jelentés eltérő, de többnyire magas megbízhatóságot rendel az alábbi kockázatok növekedéséhez: az éghajlat XXI. századi és az azt követő változásai miatt a fajok jelentős részénél a kihalás kockázatának növekedésével kell számolni, különösen mivel az éghajlatváltozás más kihívásokkal együtt jelentkezik. A jövőbeli kockázatok magas fokát jelzi az a megfigyelés, hogy a jelenlegi, ember által előidézett éghajlatváltozás mértékénél kisebb mértékű, természetes tényezőkre visszavezethető globális éghajlatváltozás az ökoszisztémák jelentős területi eltolódását és fajok kipusztulását idézte elő az elmúlt több millió évben. A part menti rendszerek és az alacsonyan fekvő területek ki vannak téve a tengerszint emelkedésével járó kockázatoknak, ráadásul a tengerek szintje a globális átlaghőmérséklet stabilizálása esetén is még évszázadokig emelkedni fog.

Az éghajlatváltozás az élelmezésbiztonságot is aláássa. A XXI. század közepére és az azt követően előrevetített éghajlatváltozás következtében a tengerben élő fajok globális átrendeződése, biodiverzitásának csökkenése az arra érzékeny térségekben kihívás elé állítja a fenntartható halászatot és egyéb ökoszisztéma-szolgáltatásokat. A trópusi és mérsékelt övi régiókban a hőmérsékletek a 
XX. század végihez képesti $2{ }^{\circ} \mathrm{C}$-os vagy azt meghaladó növekedése alkalmazkodás nélkül negatívan befolyásolja a búza-, a rizs- és a kukoricatermesztést, de vannak olyan területek, ahol a változás előnyös lehet. A globális hömérséklet $4{ }^{\circ} \mathrm{C}$-os vagy annál nagyobb emelkedése pedig - az egyre növekvő élelmiszerigénnyel együtt - nagy élelmezésbiztonsági kockázatot jelent az egész világon. Az éghajlatváltozás a becslések szerint csökkenteni fogja a megújuló felszíni és felszín alatti vízkészleteket a száraz szubtrópusi régiók többségében, és növelni fogja a vízért való versenyt az egyes ágazatok között.

Az évszázad közepére az éghajlatváltozás hatással lesz az emberi egészségre, fóleg azáltal, hogy súlyosbítja a ma is létező egészségügyi problémákat. Az éghajlatváltozás hatására számos régióban nő majd a betegségek száma a XXI. században, különösen az alacsony jövedelemmel rendelkező fejlődő országokban. A legpesszimistább RCP8.5 éghajlatváltozási forgatókönyv szerint 2100-ra a magas hőmérséklet és légnedvesség az év egy részében várhatóan veszélyezteti majd a mindennapos emberi tevékenységeket, beleértve az élelmiszertermelést és a szabadban végzett munkát is. A városi területeken az éghajlatváltozás növelni fogja a hőhullámokból, a viharokból, a szélsőséges csapadékokból, a folyók menti és tengerparti áradásokból, a földcsuszamlásokból, a légszennyezésből, a szárazságból, a vízhiányból, a tengerszint emelkedésből és a hirtelen kialakuló viharok keltette hullámokból eredô kockázatokat. Fontos megjegyezni, hogy ezek a kockázatok még erősebben jelentkeznek azoknál, akiknél hiányzik az alapvetó infrastruktúra, és nincsenek szolgáltatások, vagy a veszélyeknek egyébként is kitett helyeken élnek. A vidéki területeken súlyos következményekkel kell számolni a hasznosítható vízkészlet és a vízzel való ellátottság, az élelmezésbiztonság, továbbá az infrastruktúra és a mezőgazdasági jövedelmek vonatkozásában. Az élelmiszer és a nem élelmiszer célú növények termesztésére használt területek eltolódnak szerte a világban. A gazdasági károkat fokozza az emelkedő hőmérséklet, azonban az éghajlatváltozás okozta globális gazdasági hatásokat jelenleg nehéz megbecsülni. A szegénység kérdésének szempontjából vizsgálva az éghajlatváltozás hatásai a becslések szerint lassítják a gazdasági növekedést, megnehezítik a szegénység elleni küzdelmet. Ezen kívül tovább csökkentik az élelmezésbiztonságot, fenntartják a meglevő szegénységi csapdákat, és újakat is teremtenek, különösen a városokban és azokban a gócpontokban, ahol éhínséggel kell számolni. A becslések szerint az éghajlatváltozás hatására fokozódni fog a lakosság elvándorlása az érintett területekről. Azok a népcsoportok, amelyeknél nem állnak rendelkezésre erőforrások a tervszerúen lebonyolított áttelepüléshez, nagyobb mértékben vannak kitéve a szélsőséges időjárási jelenségeknek, különösen az alacsony jövedelmú, fejlődő országokban. Az éghajlatváltozás közvetetten növeli az erőszakos konfliktusok kockázatát, mivel felerősíti azon tényezőket, amelyek bizonyítottan az ilyen típusú konfliktusok okai szoktak lenni, mint a szegénység vagy a gazdasági válságok.

\section{Hazai éghajlati trendek}

Noha az előző fejezetben ismertetett válságok, veszélyek nem érintik közvetlenül régiónkat, fontos kiemelni, hogy egy globálisan melegedő környezetben élünk, ahol a gyakoribb és hevesebb szélsőséges időjárási események gazdasági károkat okoznak, konfliktusokhoz vezetnek több régióban, az élelmezés biztonsága kérdéses sokfelé. $\mathrm{Az}$ élelmiszerek drágulása, a társadalmi konfliktusok esetleges begyuurúzése a térségünkre is hatással lehet. Európa országai összességében kevésbé sérülékenyek, mivel az alkalmazkodóképességünk jobb, ennek növeléséhez pedig rendelkezünk megfelelő stratégiákkal. Az OMSZ is hozzájárult a második Nemzeti Éghajlatváltozási Stratégia (NÉS2 2018) kidolgozásához éghajlati monitoring információkkal és regionális klímamodell szimulációkkal is. Ebben a cikkben a megfigyelt hazai éghajlati változásokat mutatjuk be az OMSZ Éghajlati Osztályán végzett vizsgálatok eredményei alapján.

Az éghajlati monitoring a meteorológiai méróhálózatban rögzített adatsorok alapján történik. Ezek elemzésével ismerhetjük meg és követhetjük nyomon az éghajlati állapot alakulását hosszú távon. Az OMSZ adatarchívumában tárolt, korábban évkönyvekben, ma már digitálisan rendezett adatok képezik a nemzeti éghajlati adatbázist, ami nemzeti kincs, egyedüli hiteles alapja az ország éghajlatát vizsgáló kutatásoknak. Az elemzéseinket reprezentatív, ellenőrzött, homogenizált mérésekre alapozzuk. Az OMSZ Éghajlati Osztályán adathomogenizálást végzünk a mérési körülmények okozta inhomogenitások kiküszöbölésére (Szentimrey, 1999; Izsák és Szentimrey 2020). Ezen kívül térbeli reprezentativitást biztosító interpolációs eljárást is alkalmazunk annak érdekében, hogy jó minőségú adatsorokat állítsunk elő az éghajlati vizsgálatokhoz (Szentimrey-Bihari 2007).

A múszeres megfigyelések kezdete óta a rendelkezésre álló források alapján, az ezredforduló és az azt követő évek bizonyultak a legmelegebbnek Magyarországon is. A több mint egy évszázadot felölelő elemzéseink szerint a hazai melegedés összhangban van a globális felszínhőmérséklet alakulásával, noha az évről évre fellépő változékonyság nagyobb. Ezt támasztja alá az 1 . ábra, ami a globális átlagos (szárazföldek felett mért levegő és a tengervíz hőmérsékletének átlaga) anomáliát és a hazai országos évi középhőmérsékletek anomáliát mutatja az 1961-1990-es referencia időszakhoz viszonyítva. A Meteorológiai Világszervezet ajánlása szerint az éghajlatváltozás szemléltetésére ezt az időszakot használjuk referenciaként (WMO 2017). Több adatközpont is foglalkozik globális adatsorok elóállításával, karbantartásával. Ezek közül a HaDCRUT5 adatbázist (Morice et al. 2021) választottuk alapul az 1 . ábráboz. A kisebb terület miatt nyilvánvalóan nagyobb a változékonyág Magyarországon, kevésbé sima a görbe, mint földi átlagban. Ha lineáris trendet illesztünk a globális és a hazai sorra, akkor némileg magasabb trendet kapunk Magyarországra: a hazai változás $1,2{ }^{\circ} \mathrm{C} 1901$-tól, míg a globális sor 


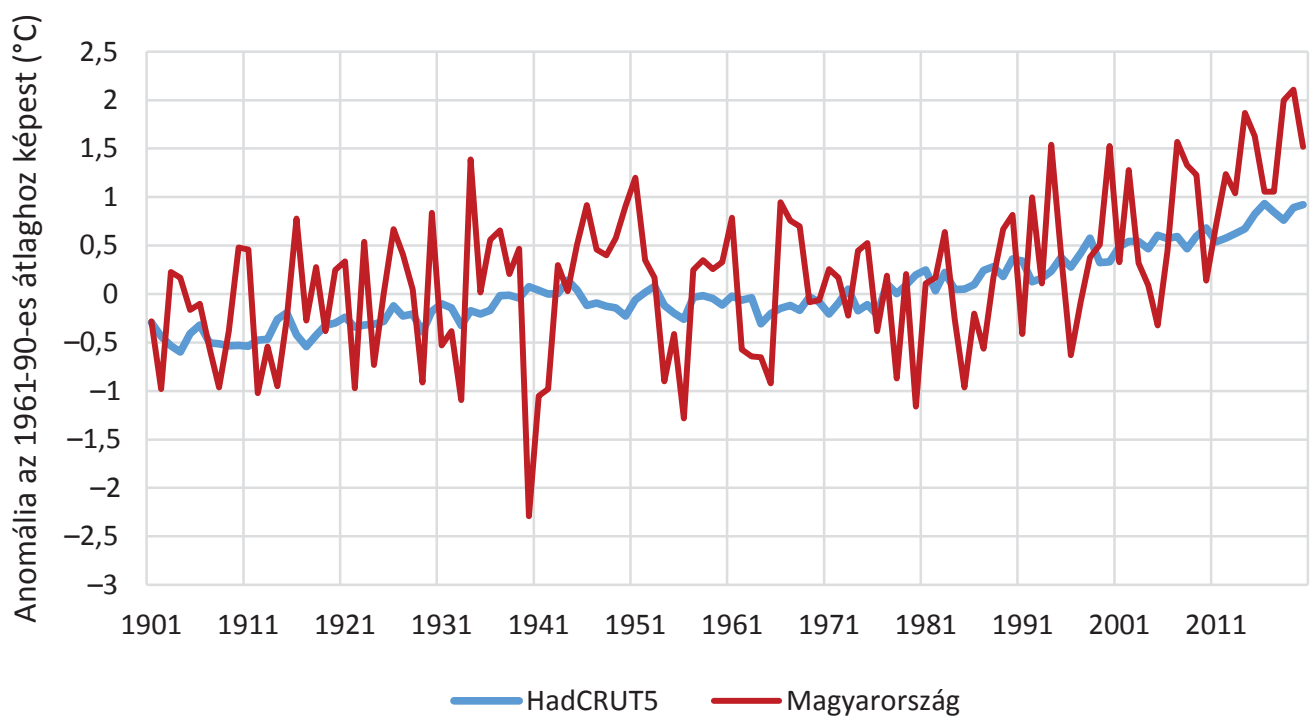

1. ábra

A globális felszínhőmérsékletek és a magyarországi évi középhőmérsékletek anomáliái az 1961-1990-es referencia időszakhoz viszonyítva 1901 és 2020 között (forrás: a szerzők ábrája)

1,1 ${ }^{\circ} \mathrm{C}$-os emelkedést jelez. Fontos hangsúlyozni azt is, hogy nem törvényszerü, hogy a legmelegebb évek egy időben lépjenek fel globálisan, Európában és Magyarországon. Míg Európában 2020 a legmelegebb volt a kiterjedt mérések kezdete óta, addig Magyarországon a nyolcadik helyre került a rangsorban.

A csapadék térben és időben is változékony térségünkben, így az éghajlatváltozás hatására bekövetkező egyirányú változásokat nehezebb kimutatni, mint a hőmérséklet esetén. Míg Észak- és Nyugat-Európában a melegedési tendenciával együtt több csapadék hullik, addig nálunk a Földközi-tenger térségéhez hasonlóan éves szinten valamivel kevesebb. Az éves összeg kismértékú, 3\%-os, nem szignifikáns csökkenést jelez 1901 és 2020 között (2. ábra). A legutóbbi évek csapadékviszonyait inkább a szélsőségesség, aszályok, özönvízszerű esőzések előfordulása jellemzi. A legszárazabb évek az ezredforduló után következtek be, ez növekvő aszályhajlamra utal. Ugyanakkor 2010-ben rendkívül sok csapadék hullott, ami kiugró az idősorban, kisebb valószínúségü, mint az igen száraz évek előfordulása. A tartósan száraz, aszályos időszakok növekedése, valamint a csapadék térbeli és időbeli eloszlásának változása miatt a talaj nedvesség-ellátottságának romlása is növeli az aszályhajlamot. Így a mainál nagyobb területeken kell aszályra számítani. Ez a mezőgazdasági tevékenység teljes spektrumára negatív hatással lesz, és csökkenti az élelmiszerellátás biztonságát.

Az éves átlagok mellett a hőmérséklet és a csapadék évi menetében bekövetkezett változásokat is nyomon követ-

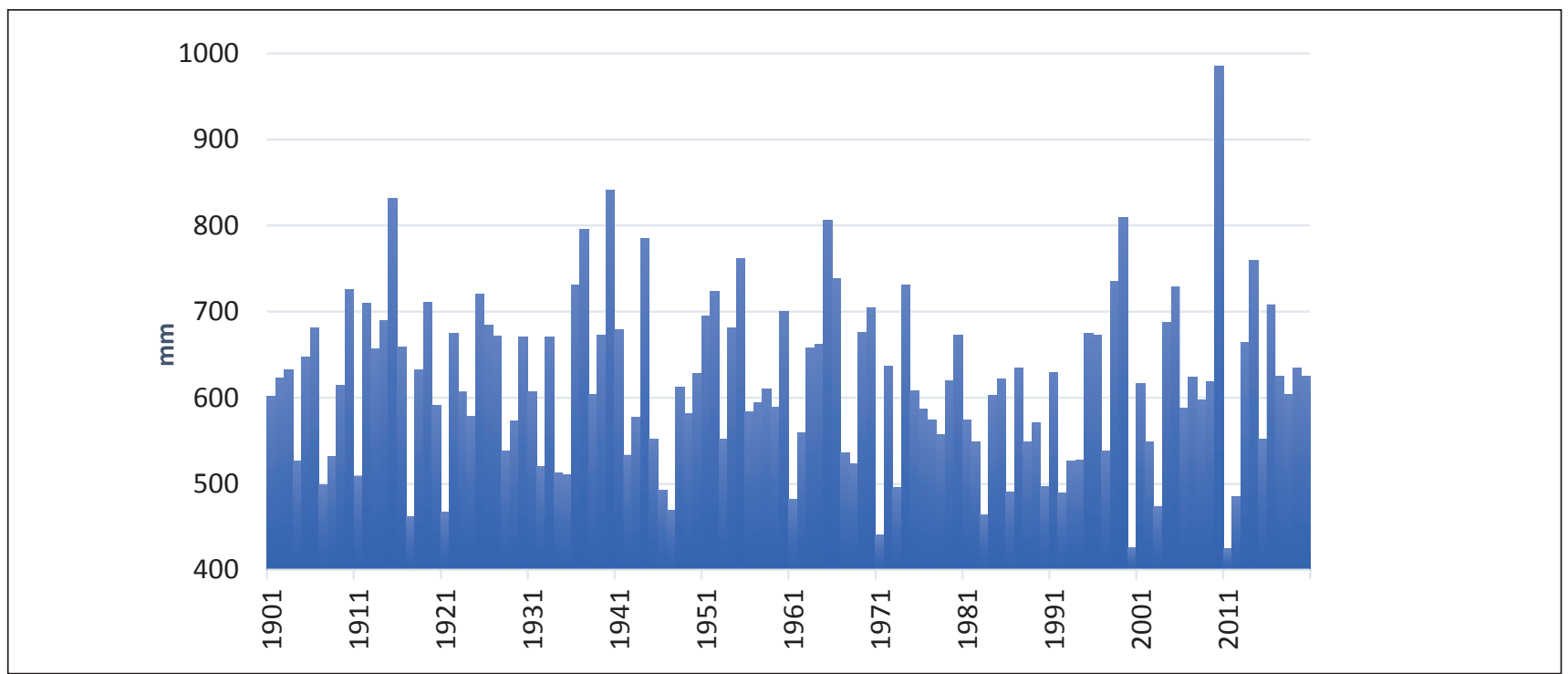

2. ábra

| Az évi országos átlagos csapadékösszeg Magyarországon 1901 és 2020 között (forrás: a szerzők ábrája) 

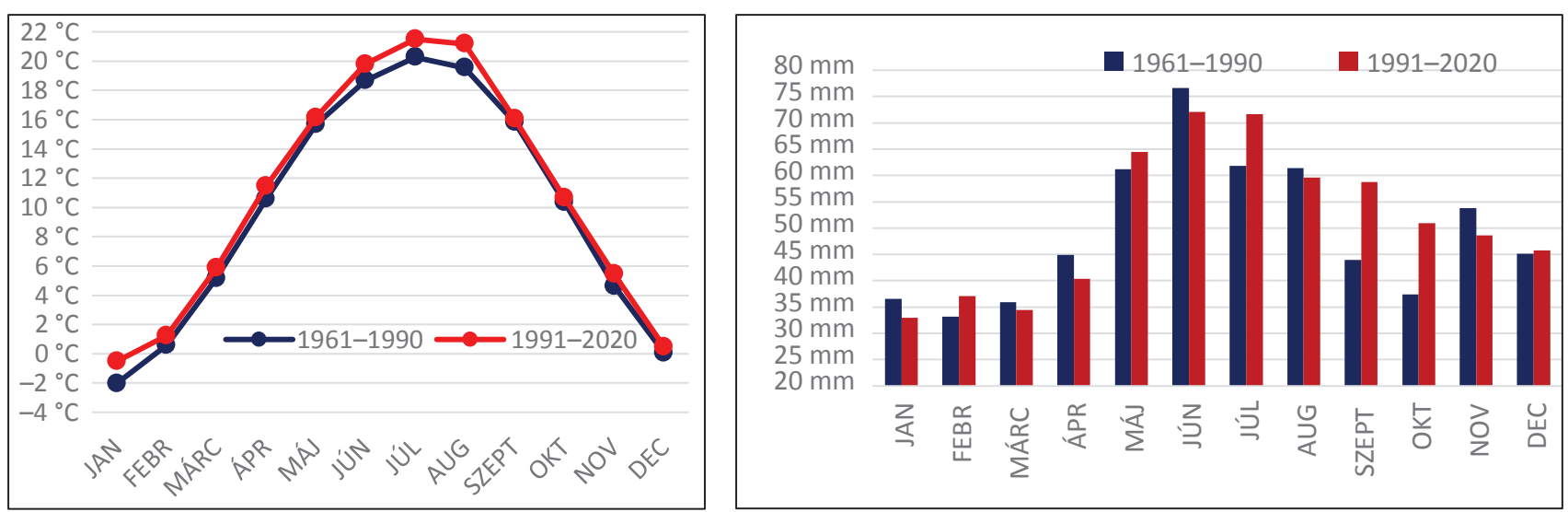

3. ábra

| A havi középhőmérsékletek és csapadékösszegek országos átlagai különböző normál időszakokban (forrás: a szerzők ábrája)

hetjük a 3. ábrán. Az 1961-1990-es átlagokhoz képest minden hónap melegebb a jelen éghajlatot leginkább leíró 1991-2020-as normál időszakban. A legnagyobb melegedést a nyári hónapokban, különösen augusztusban $\left(1,63{ }^{\circ} \mathrm{C}\right)$ látjuk, de a januárok is melegedtek 1,51 ${ }^{\circ} \mathrm{C}$-kal az 1961-1990-es normálhoz viszonyítva. A korábbi normált tekintve február volt a legszárazabb hónap, míg az 1991-2020-as időszakban már január a legszárazabb, majd a március, s csak ezt követi a február. A legcsapadékosabb hónap továbbra is a június, de a júliusi átlagos összeg alig marad el ettől. Az első két őszi hónap jelentősen csapadékosabbá vált, ami azt eredményezi, hogy eltûnt a novemberi másodlagos csapadékmaximum, ami a korábbi normál időszakban még megfigyelhető volt.

Az OMSZ honlapján elérhetők a havi, évszakos és éves éghajlati visszatekintők, amelyek bemutatják az aktuálisan zárult időszak anomáliáit és szélsőségeit (visszatekintők/met.bu 2021). Az Országos Katasztrófavédelmi Főigazgatóságot rendszeresen ellátjuk ilyen típusú éghajlati információkkal, ezzel is segítve a természeti veszélyekre való felkészülés folyamatát.

\section{A hazai éghajlati szélsőségek változása}

Noha az átlagok eltolódása gyorsan zajlik éghajlati skálán, az ezekhez való alkalmazkodás lehetne sikeres, viszont az emberi tevékenység következtében bizonyos szélsőségek gyakoribbá váltak, jellemzően a múlt század közepétől (IPCC 2013), ezekhez alkalmazkodni már nagyobb kihívást jelent. A gyakrabban előforduló szélsőséges időjárási helyzetek komoly kártétellel járnak, ezért jól megalapozott alkalmazkodási lépéseket kell tenni a károk megelőzése érdekében. A természetes ökoszisztémákat és minden szektort, így az egészségügyet, a mezőgazdaságot, a vízgazdálkodást, az energiaellátást és a turizmust is a szélsőséges időjárási és éghajlati események sújtják leginkább. Az épített környezetre, a kritikus infrastruktúrákra is ezek jelentik a legnagyobb veszélyt.

Az egyik kockázati tényező, amelyet kezelnünk kell Magyarországon is, a meleg szélsőségek gyakoribbá vá- lása. A 2020-szal záruló legutóbbi tíz év átlagát tekintve évente 14 hőhullámos nap fordult elő országos átlagban. A növekedés 6 napot tesz ki a múlt század elejétől, ami egyértelmúen a meleg szélsőségek növekvő számát jelzi. A növekmény az 1981 utáni intenzív melegedés időszakában sok területen, főként a Kisalföldön és a Dél-Alföldön a két hetet is meghaladja (4. ábra). A hosszabbá és intenzívebbé váló hőhullámok nagyobb kockázatot jelentenek az idősek és a betegek számára, s az egészségügyi rendszert is jobban megterhelik. A hőmérsékleti viszonyok változása következtében módosuló energiaigényekre kell felkészülni: télen az energiaszükséglet mérséklődésére, nyáron a hütési villamosenergia-igény jelentős növekedésére kell számítani. A hosszú hőhullámok sok háztartás számára azt jelentik, hogy a lakás nyári temperálása, hûtése válik szükségessé, ami nem csak az energiaigények, hanem a lakás felújítását, gépészetének átalakítását is szükségessé teszi. Ezt a lakásállomány felújítási programjainak tervezése során célszerü figyelembe venni.

Másik fontos éghajlati változás hazánkban is, hogy intenzívebbé vált a csapadékhullás, ezt az is alátámasztja, hogy a közel azonos évi mennyiség lényegesen kevesebb napon hullik le. A csapadékos napok évi száma 17 nappal csökkent 1901 óta. A 20 mm fölötti nagy csapadékú napok országos átlaga évről évre nagy változékonyságot mutat a teljes XX. századot lefedő, 2020-ig kiterjesztett adatsoron (5. ábra). A XX. században az 1940-es évekig emelkedő, majd az 1990-es évtized végéig csökkenő jelleg mutatkozott, ezt követően viszont több évben is kiugróan magas számban fordultak elő 20 mm-t meghaladó csapadékú napok. A legtöbb, országos átlagban közel 9 ilyen nap előfordulása a legcsapadékosabb 2010es évhez köthető. A növekedés országos átlagban közel 2 nap, de az 1981-2020 közötti időszakban vannak csökkenést mutató területek is. A változás területi eloszlása igen változatos, a legnagyobb (több mint 5 napos) növekedés a Bükk környezetében mutatkozik, a Dráva mentén és a Nyírségben viszont csökkenés rajzolódik ki. Az intenzitás növekedése hosszabb száraz időszakokkal párosul. Ez kihathat a felszíni és felszín alatti vizek mennyi- 

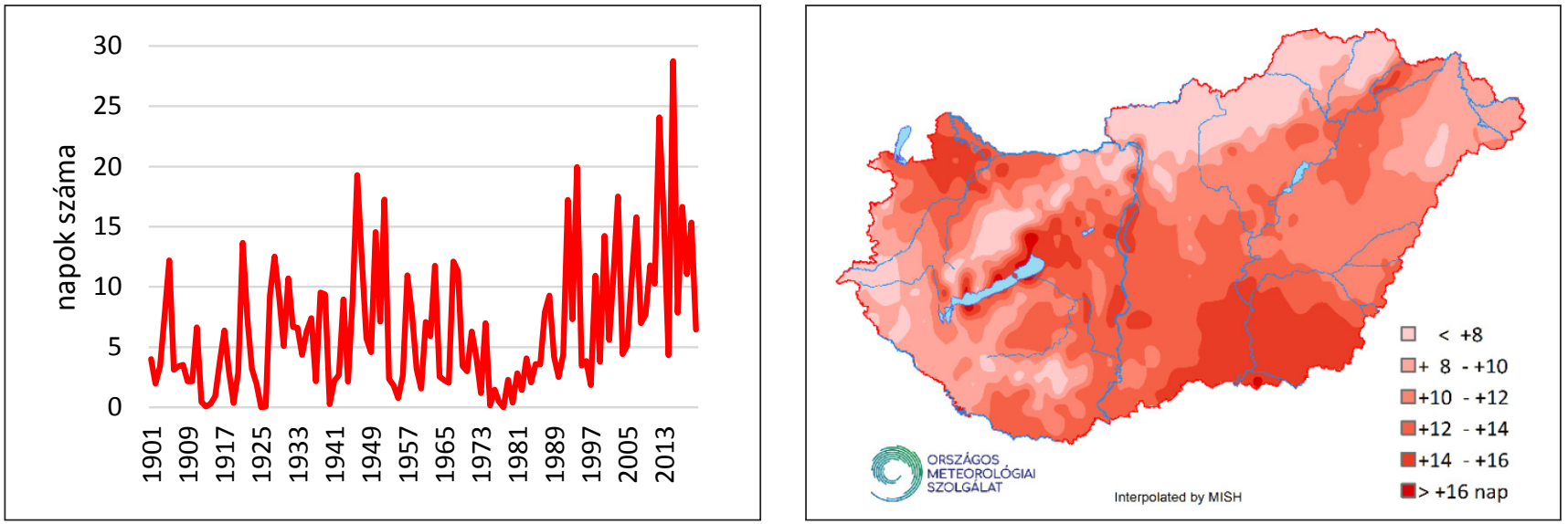

4. ábra

A hőhullámos napok (napi középhőmérséklet $>25^{\circ} \mathrm{C}$ ) éves számának országos átlaga (homogenizált, rácspontokba interpolált adatok alapján) 1901 és 2020 között és a hóhullámos napok számának változása 1981-tôl 2020-ig lineáris trend feltételezésével.

(forrás: a szerzók ábrája, térkép Bíróné Kircsi Andrea)
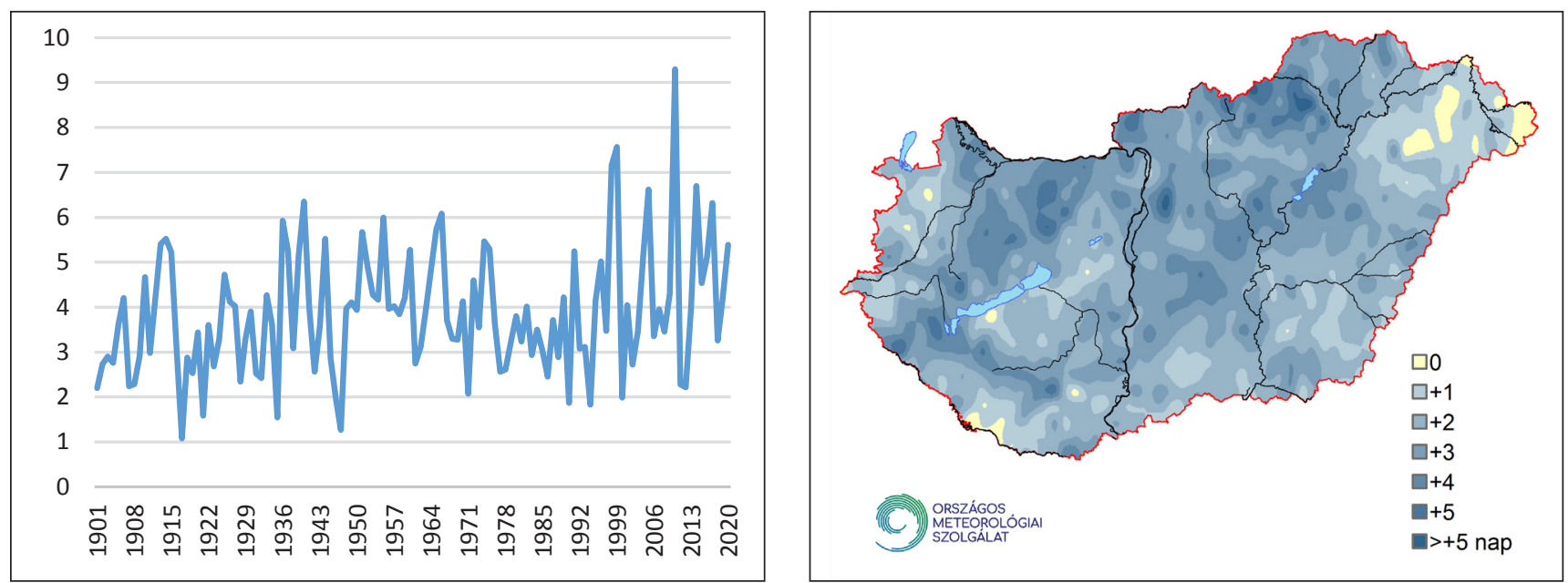

5. ábra

A 20 mm fölötti csapadékú napok országos átlaga (homogenizált, rácspontokba interpolált adatok alapján) 1901 és 2020 között és a 20 mm-t meghaladó csapadékú napok számának változása 1981-tôl 2020-ig lineáris trend feltételezésével.

(forrás: a szerzók ábrája, térkép Bíróné Kircsi Andrea)

ségére és összetételére, és ezen keresztül többek között az ivóvízellátásra, a csatornahálózatra, a kritikus infrastruktúrára, a mezőgazdaságra és az erdőgazdálkodásra is. A rendszertelenül előforduló és intenzívebbé váló csapadék a hegy- és dombvidéki területeken, valamint a kisvízgyưjjtőkön és városi környezetben növeli a hirtelen árvizek, villámárvizek és az áradások gyakoriságát.

\section{A hazai éghajlati változások okozta biztonsági kockázatok kezelése}

Az OMSZ szakemberei a Katasztrófavédelem szereplőivel a KEHOP-1.1.0-15-2016-00003, „Katasztrófa-kockázatértékelési rendszer” projekt keretében azonosítottak bizonyos időjárási szélsőségeket, amelyek már most is sújtják régióinkat, s a jövőben ezek gyakoribbá, esetenként erősebbé válásával kell számolni. A projekt általános célkitűzése egy olyan térinformatikai alapú, online, központosított katasztrófa-kockázatértékelési rendszer kialakítása és múködtetése, amellyel az egész ország területét lefedve, település szinten lehetséges katasztrófaveszélytípusonként a kockázati területek azonosítása, kockázati szintek meghatározása. Ez a közös adatbázisrendszer az érintett társszervezetek informatikai rendszerének interfészes összekapcsolásával jön létre, amely stratégiai és taktikai szinten biztosítja a katasztrófahelyzetekre, veszélyhelyzetekre való felkészülést, megelőzést, elősegíti a települések egységes adatbázis alapján történő katasztrófavédelmi osztályba sorolását, azok pontosítását, a védelmi tervezést, a felkészülési tervek kidolgozását, támpontot biztosít a területi tervezésben, valamint tájékoztatást nyújt a lakosság számára az egyes kockázati típusok esetében a kockázatok szintjéról.

Ezzel megvalósul egy új és egységes, Magyarország teljes területére kiterjedő katasztrófakockázat-értékelés, a társszervek adatainak és szolgáltatásainak legmagasabb fokú integrációja, valamint az eredmények széles körú megosztása a katasztrófavédelem illetékes területei és a társszervezetek részére. Az OMSZ által a projekt kereté- 
ben szolgáltatott adatokat egyrészt a publikus riasztási információk, másrészt néhány aktuális megfigyelési adat (szél, hőmérséklet, csapadék, radarmérések), harmadrészt időjárási előre jelző modell adatok (balatoni hullámmagasság-előrejelzés, talajnedvesség-analízis) alkotják. Az OMSZ vezeti az „Időjárási szélsőségek” munkacsoportot, melyben kockázati térképeket készítettünk hőség, extrém hideg, erős szél, nagy csapadék előfordulására vonatkozóan éghajlati idősorok alapján. Az állomási adatsorokból egy sưrú, $0,05^{\circ}$-os felbontású, illetve a változatos domborzatú körzetekben további pontokat is tartalmazó rácshálózatra napi adatsorok készültek elsó lépésben, majd a rácsponti értékekből települési és járási adatokat határoztunk meg. A településeket, illetve járásokat öt veszélyeztetettségi kategóriába soroltuk az alábbiak szerint: csekély mértékben veszélyeztetett, átlagosnál kisebb veszélyeztetettségü, átlagosan veszélyeztetett, átlagosnál nagyobb veszélyeztetettségü, és a fokozottan veszélyeztetett az egyes időjárási veszélyek tekintetében.

Az OKF és OMSZ adatbázisok összekötése lehetővé teszi majd a jövőben, hogy például a tűzoltó vonulási adatokat, a klimatizált helyeket, vagy az erdőket azonosító adatbázisokat felhasználva becslést adjunk az időjárásból eredő kockázatra. Négy időjárási szélsőségre vonatkozóan készül ilyen elemzés: szél, hófúvás, extrém hideg, hőség. Ezt össze lehet majd párosítani a veszélyjelző rendszer aktuális állapotával, s az így létrejövő kétdimenziós táblázat egyik tengelyén a kockázat, a másikon az időjárási veszély jelenik meg, s ezáltal a fokozottan kitett területek azonosíthatók. Bízunk benne, hogy ez az együttmúködés hozzájárul majd az éghajlatváltozás okozta biztonsági kihívások kezeléséhez, csökkenti a katasztrófa kockázatot, és a sérülékenységet a fokozottan kitett régiókban is.

\section{Összefoglaló megjegyzések}

Globálisan melegedő környezetben élünk. Az éghajlati rendszer minden elemét érintik a változások. A vízciklus komponenseinek az eltolódása és a fokozott terheléssel járó hőségperiódusok jelentik a legnagyobb kockázatot az emberi egészségre, a természetes ökoszisztémákra minden termelő és szolgáltató szektorra. A klímaváltozás hatásaira való eredményes felkészüléshez elengedhetetlen a már bekövetkezett változások irányának és mértékének ismerete és a regionális klímamodell-szimulációk eredményeinek beépítése a felkészülési stratégiákba. Az utóbbi évtizedekben a térségünkben jelentkező magas hőmérsékleti anomáliák és az egymást követő évek szélsőséges csapadékviszonyai miatt különösen indokolt az éghajlati állapot folyamatos nyomon követése. A biztonsági kockázatok értékeléséhez fontos figyelembe venni az éghajlati elemekben bekövetkezett és várható válto- zások mellett azt is, hogy a hatások és a sérülékenység a társadalmi és gazdasági tényezôktől is erôsen függ, mivel azok egyértelmúen meghatározzák az alkalmazkodó képességet. Az alkalmazkodás és a mérséklés egymást kiegészítő stratégiák az éghajlatváltozás kockázatainak csökkentésében és kezelésében. Az elkövetkezendő néhány évtizedre tervezett, jelentős mértékű kibocsátásmérséklések csökkenthetik az éghajlati kockázatokat a XXI. században, és tovább növelhetik a hatékony alkalmazkodás lehetőségeit, tovább csökkenthetik a mérséklés költségeit és kihívásait hosszabb távon.

\section{Hivatkozások}

IPCC (2013) Summary for Policymakers Climate Change 2013: the Physical Science Basis. Contribution of Working Group I to the Fifth Assessment Report of the Intergovernmental Panel on Climate Change. (eds Stocker T. F. et al.) Cambridge-New York, NY: Cambridge University Press

IPCC (2014a) Climate Change 2014: Synthesis Report. Contribution of Working Groups I, II and III to the Fifth Assessment Report of the Intergovernmental Panel on Climate Change [Core Writing Team, R.K. Pachauri and L.A. Meyer (eds.)]. IPCC, Geneva, Switzerland, pp. 1-31.

IPCC (2014b) Éghajlatváltozás 2014 Szintézis Jelentés. Döntéshozói Összefoglaló. https://www.ipcc.ch/site/assets/uploads/2018/ 02/ar5-spm-syr_Hungarian.pdf

Izsák, B., \& Szentimrey, T. (2020) To what extent does the detection of climate change in Hungary depend on the choice of statistical methods? Int J Geomath, Vol. 11. No. 17. https://doi.org/ 10.1007/s13137-020-00159-7

Morice, C. P., Kennedy, J. J., Rayner, N. A., Winn, J. P., Hogan, E., Killick, R. E., Dunn, R. J. H., Osborn, T. J., Jones, P. D., \& Simpson, I. R. (2021) An updated assessment of near-surface temperature change from 1850: the HadCRUT5 dataset. Journal of Geophysical Research, Vol. 126. No. 3. DOI: 10.1029/2019JD032361

FAO (2020) Food and Agriculture Organization of the United Nations, 2020: The State of Food Security and Nutrition in the World 2020. Transforming food systems for affordable healthy diets, http://www.fao.org/3/ca9692en/online/ca9692en.html

NÉS2 (2018) A második Nemzeti Éghajlatváltozási Stratégia. https:// nakfo.mbfsz.gov.hu/sites/default/files/files/N\%C3\%89S_ Ogy\%20\%C3\%Alltal\%20elfogadott.PDF

Szentimrey, T. (1999) Multiple Analysis of Series for Homogenization (MASH). Proceedings of the Second Seminar for Homogenization of Surface Climatological Data, Budapest, Hungary; WMO, WCDMP-No. 41, pp. 27-46.

Szentimrey, T., \& Bihari, Z. (2007) Mathematical background of the spatial interpolation methods and the software MISH (Meteorological Interpolation based on Surface Homogenized Data Basis). Proceedings of the Conference on Spatial Interpolation in Climatology and Meteorology, Budapest, Hungary, 2004, COST Action 719, COST Office, 2007, pp. 17-27.

visszatekintők/met.hu (2021) https://www.met.hu/eghajlat/magyarorszag_eghajlata/eghajlati_visszatekinto/

WMO (2017) WMO Guidelines on the calculation of Climate Normals. WMO-No. 1203, https://library.wmo.int/index.php?lvl= notice_display\&id $=20130$

WMO (2021): State of the Global Climate 2020. WMO-No. 1264, State of the Global Climate 2020 (WMO-No. 1264) | E-Library

A cikk a Creative Commons Attribution 4.0 International License (https://creativecommons.org/licenses/by-nc/4.0/) feltételei szerint publikált Open Access közlemény, melynek szellemében a cikk bármilyen médiumban szabadon felhasználható, megosztható és újraközölhető, feltéve, hogy az eredeti szerző és a közlés helye, illetve a CC License linkje és az esetlegesen végrehajtott módositások feltüntetésre kerülnek. 